\title{
KOMUNIKASI DALAM IMPLEMENTASI PENGELOLAAN SAMPAH DI KOTA PALU
}

\author{
Rusmawaty Bte. Rusdin \\ Program Studi Ilmu Pemerintahan, Fakultas Ilmu Sosial dan Ilmu Politik, Universitas Tadulako \\ Email: rusmawatyrusdin19@gmail.com
}

\begin{abstract}
ABSTRAK
Upaya yang dilakukan pemerintah untuk mendukung dan mengurangi masalah sampah pemerintah kota Palu dengan mengeluarkan kebijakan melalui pembuatan peraturan daerah nomor 3 tahun 2016 mengenai pengelolaan sampah. Pada penelitian ini menggunakan teori Edward III. Metode penelitian yang digunakan adalah kualitatif dengan pendekatan jenis penelitian deskriptif kualitatif. Adapun sumber data yang digunakan adalah sumber data primer yaitu melalui wawancara dan sumber data sekunder yakni melalui dokumen serta pendukung yang lain. Teknik pengumpulan data yang digunakan melalui studi lapangan melalui wawancara mendalam dan dokumentasi. Temuan penelitian dalam penelitian ini adalah upaya pelaksanaan implementasi kebijakan yang dilakukan oleh pihak pemerintah kota Palu dalam pengeloaan sampah dari aspek komunikasi yaitu mengenai sosialisasi yang di lakukan oleh pemerintahan kelurahan belum menyeluruh kepada setiap RT/RW yang ada di kelurahan. Dari segi sumber daya, masih banyak kekurangan-kekurangan dalam hal sarana maupun prasarana untuk menunjang terlaksananya kebijakan dengan baik. Kemudian dari disposisi atau komitmen yang di bangun oleh pemerintah kelurahan untuk menjalankan peraturan masih kurang perlu keseriusan dan kesungguh-sungguhan dalam menerapkan peraturan yang ada. Dan yang berikutnya dilihat dari Struktur Birokrasi yaitu masih kurangnya pembentukan para anggota pengelolah sampah dan tidak maksimalnya kordinasi yang dilakukan oleh pihak keluraha dengan pemerintahan yang beradah di bawahnya yaitu RT dan RW mengakibatkan di beberapa RT/RW masih belum terbentuk pengelolah sampah seperti yang di inginkan dalam peraturan yang ada.
\end{abstract}

\section{Kata Kunci : Komunikasi; Sumber Daya; Disposisi; Struktur}

\section{Submisission: 26 April 2021}

\section{Pendahuluan}

Sampah menjadi masalah terbesar dalam kehidupan sehari-hari ini baik di wilayah di perkotaan namun juga wilayah di pedesaan masih menyisahkan permasalahan (Mahyudin, 2017). Keberadaan sampah tidak dapat dihindari sehingga perlu pengelolaan sampah yang baik sehingga tidak mengakibatkan lingkungan tercemar (Parwata et al., 2011) . Akibat sampah yang tidak tertangani dengan baik akan mengganggu estitika lingkungan serta dapat menimbulkan penyakit. Pengelolaan sampah saat ini diatur berdasarkan UU No 18 Tahun 2008 serta PP No 81 Tahun 2012 di lakukan dengan dua fokus utama yakni pengurangan dan penanganan sampah. Pengurangan sampah yang dimaksud dalam undang-undang maupun peraturan pemerintah dikatakan bahwa mulai dari sumber yang timbulkan sampah sampai pada tahap pengelolaan akhir sampah. Pengurangan sampah dibutuhkan partisipasi aktif masyarakat maupun pihak yang diberikan tanggungjawan terhadap pengelolaan sampah (Hernawati \& Saleh, 2015). Data kementrian lingkungan hidup 
jumlah timbunan sampah pada tahun 2020 kira-kira mencapai 67,8 ton yang diperkirakan akan terus bertambah seiring pertumbuhan penduduk sehingga perlu penanganan sampah yang baik (Aditya, 2020).

Sampah diartikan sisa-sisa material yang dibuang sehingga cenderung merusak lingkungan setempat (Djunaidi, 2018). Sampah tidak hanya menimbulkan persolan kebersihan namun dampak dampak sampah bisa mempengaruhi kesehatan manusia jika sampai tidak ditangani cepat sebab masih ada sebagian masyarakat membuang sampah sembarangan. Untuk mengatur pengelolaan sampah pemerintah Kota Palu mengeluarkan kebijakan terkait pengelolaan sampah melalui peraturan daerah No 11 Tahun 2013 selanjutnya mengalami perubahan melalui perubahan peraturan nomor 3 Tahun 2016 dalam rangka untuk meningkatkan kesehatan masyarakat, memperbaiki kualitas lingkungan, menjadikan sampah sebagai sumber daya yang memiliki nilai ekonomi untuk masyarakat serta meningkatkan pelayanan yang bersifat efesien dan efektif.

Penanganan sampah sesungguhnya menjadi tanggungjawab bersama(Fadli et al., 2016) bukan semata-mata tugas dan wewenang pemerintah Kota Palu namun masyarakat perlu meningkatkan kesadaran terhadap pengelolaan sampah yang baik. Sistem komunikasi menjadi siklus terpenting dalam merespon pengelolaan sampah di kota Palu. Defenisi komunikasi adalah proses penyampaian informasi, ide, gagasan kepada orang lain melalui sarana dan saluran tertentu berupa pikiran dan perasaan (Cangara, 2016). Menurut Frank Dance bahwa konsep redukasi ketidakpastian merupakan hal terpenting dalam komunikasi (Littlejohn, Stephen. W. \& Foss, 2011). Untuk mengurangi ketidakpastian komunikasi muncul dengan sendirinya dalam rangka untuk melindungi serta memperkuat ego dalam berinteraksi baik secara individual maupun secara kelompok. Dalam pengelolaan sampah diperlukan komunikasi oleh masyarakat, pemerintah maupun pihak swasta.

Kompleksnya masalah sampah di kota Palu diakibatkan oleh kurangnya kesadaran, partisipasi masyarakat yang masih tergolong rendah terhadap peduli sampah serta kurangnya komunikasi sehingga sinergitas antara pemerintah, masyarakat dan pihak swasta terhadap pengelolaan sampah tidak memperlihatkan titik temu. Sementara persoalan sampah tidak dapat dikerjakan secara sendirisendiri keterlibatan semua stake holder dibutuhkan untuk mengatasi persoalan sampah sehingga implementasi kebijakan bisa berjalan dengan baik. Pada dasarnya dalam pengelolaan sampah di Kota Palu dibutuhkan sistem komunikasi yang baik sehingga masalah sampah bisa diatasi dengan baik sehingga terciptanya lingkungan bersih dan sehat.

Kehadiran peraturan daerah terkait pengeloaan sampah diharapkan menimbulkan kesadaran masyarakat terhadap kebersihan lingkungan sekitar serta masyrakat diharapkan mampu mengurangi jumlah sampah dan mendaur ulang sampah yang masih bernilai ekonomis seperti membuat kerajinan tangan dari limbah sampah atau membuat pupuk kompos untuk tanaman. Namun realitasnya implementasi kebijakan tidak berjalan optimal terlihat tingkat kesadaran masyarakat masih rendah terhadap peduli sampah, tempat pembuangan sampah masih belum dilengkapi sarana dan prasarana yang memadai sehingga masyarakat membuat sampah seenaknya. Kebijakan pengelolaan sampah di Kota Palu didukung dengan kehadiran satuan tugas K5 di setiap kelurahan namun masih belum efektif. Implementasi sebagai bagaian dari proses kebijakan publik tidak boleh diabaikan karena keberhasilan suatu kebijakan atau keputusan mencapai tujuan ditentukan oleh tahapan implementasi(Akib, 2010). Jika implementasi berhasil dilakukan, maka kebijakan tersebut berhasil mencapai tujuan. Jika mpementasi berhasil dilakukan, 
maka kebijakan tersebut berhasil mencapai tujuan. Untuk mencapai tujuan atau melaksanakan kebijakan diperlukan sarana dan sumber daya. Karena itu Dunn menyatakan karakteristik implementasi kebijakan adalah kebijakan yang telah diambil dilaksanakan oleh unit-unit administrasi yang memobilisasikan sumber daya finasial dan manusia (Dunn, 2003).

Implementasi kebijakan pada dasarnya sebuah kebijakan dapat mencapai sebuah tujuan dengan sebuah cara. Dalam mengimplementasikan kebijakan publik melalui dua cara yakni secara langsung melalui bentuk program atau turunan dari kebijakan publik tersebut. Sementara Budiman Rusli mengatakan bahwa implementasi kebijakan adalah kegiatan atau program yang dibuat dalam rangka mencapai sebuah tujuan yang sudah ditetapkan (Budiman, 2013 : 83). Van Meter dan Van Horn mengartikan implementasi kebijakan merupakan langkah atau tindakan yang diambil oleh pemerintah dalam rangka untuk mencapai sebuah tujuan sesuai keputusan kebijaksanaan (Agustino, 2008).

Salah satu model implementasi kebijakan yang sering digunakan adalah model yang dikemukakan George C. Edward III yang memhatikan empat aspek diantaranya komunikasi, sumber daya, disposisi dan struktur birokrasi. Komunikasi diperlukan dalam rangka melaksanakan sebuah kebijakan sehingga para pelaksana kebijakan memiliki pemahaman semakin konsisten menjalankan tugas secara efektif. Sumberdaya merupakan salah aspek dibutuhkan dalam terselenggaranya tujuan kebijakan baik sumber daya manusia maupun sumber daya finansial. Disposisi menunjukan bahwa komiten dan kejujuran dibutuhkan dalam implementasi kebijakan atau sebuah program. Sementara struktur birokrasi dibutuhkan adalah mekanisme dalam hal ini adanya standar operasional atau pedoman organisasi yang mudah dipahami dan struktur organisasi (Nugroho, 2017).

\section{Metode Penelitian}

Pada penelitian ini menggunakan metode penelitian kualitatif (Moleong, 2012) dengan pendekatan jenis penelitian deskriptif kualitatif dengan mengarahkan peneliti pengamatan penelitian secara signifikan dengan tujuan dapat menggambarkan realitas yang berkaitan dengan pengelolaan sampah. Adapun sumber data yang digunakan adalah sumber data primer yaitu melalui wawancara dan sumber data sekunder yakni melalui dokumen serta pendukung yang lain. Teknik pengumpulan data yang digunakan melalui studi lapangan melalui wawancara mendalam dan dokumentasi. Analisis data yang digunakan adalah reduksi data, penyajian data dan menarik kesimpulan (Miles, 2005).

\section{Hasil dan Pembahasan}

Sampah merupakan masalah yang sangat krusial saat ini yang perlu mendapatkan penanganan secepat mungkin agar tidak menjadi masalah serius (Suryana, 2018). Tentunya untuk menangani permasalahan sampah dibutuhkan kerjasama semua pihak diantaranya pemerintah, masyarakat dan pihak swasta. Selama ini masyarakat masih memandang persoalan sampah dari sisi negatif namun sampah bisa menghasilkan nilai ekonomis sepanjang mampu dikelola. Beberapa daerah seperti Kota Malang sampah dikelola melalui pemberdayaan masyarakat sehingga menghasilkan sebuah produk yang bernilai ekonomis sehingga dapat menambah penghasilan warga setempat (Sujiyanto, 2016).

Untuk melihat implementasi kebijakan pengelolaan sampah di kota Palu menggunakan model implementasi kebijakan yang dikemukakan oleh Edward III yang dikenal dengan menggunakan empat aspek terdiri dari komunikasi, disposisi, sumberdaya dan struktur birokrasi (Nugroho, 2017). 


\section{Komunikasi}

Komunikasi dalam suatu organisasi harus cermat memahami dan mengerti komunikasi para impelementor. Sumber informasi menjadi penting dalam berkomunikasi sebab terkadang melahirkan pemahaman yang berbeda jika sumber informasi yang didapatkan juga berbeda. Implementasi kebijakan dapat berjalan efektif dibutuhkan rasa tanggung jawab dalam melaksanakan tugas yang diamanahkan. Ketrampilan berkomunikasi dibutuhkan untuk menyampaikan sebuah pesan agar tidak terjadi distorsi dalam proses penerimaan pesan kepada implementor.

Upaya dalam rangka keberhasilan suatu implementasi kebijakan pemerintah dibutuhkan pelaksana kebijakan yang benar-benar memaham tugas yang harus dijalankan sehingga kebijakan tersebut terlaksana sesuai tujuan utama. Pada dasarnya agar tujuan dan sasaran tidak mengalami distorsi dalam proses penyampaian dibutuhkan komunikasi dan infomasi yang lengkap sebab dikhawatirkan penyampaian tujuan dan sasaran yang tidak jelas mendapatkan sejumlah penolakan dari kelompok sasaran.

Dinas kebersihan menjalankan program penanganan kebersihan melalui program pengelolaan persampahan secara internal mengkomunikasikan kepada seluruh implementor namun tidak berjalan dengan efektif. Program yang dijalankan dalam rangka untuk mengatasi kebersihan lingkungan kota Palu persoalan sampah masih sulit teratasi selain karena kurangnya kesadaran masyarakat juga karena sarana dan prasarana yang disiapkan untuk membuang sampah masih kurang. Tidak hanya itu peraturan daerah pengelolaan sampah diharapkan mampu mengatasi persoalan sampah namun realitasnya tidak demikian. Peran aktif implementor dalam hal ini dinas kebersihan perlu melalukan komunikasi yang baik sehingga informasi dapat di terima baik para pelaksana kebijakan terurama dalam hal ini petugas pengangkut sampah. Realitasnya dilapangan masih banyak sampah-sampah tidak terangkut bahkan dengan alasan petugas sampah tidak memiliki uang transporatasi kendaraan.

Dalam peraturan daerah Kota Palu No 3 tahun 2016 pasal 38 dan pasal 40 A dijelaskan bahwa Pemerintah Daerah wajib melakukan pembinaan pengolahan sampah yang salah satu caranya dengan sosialisasi dan untuk meningkatkan peran masyarakat. Hasil penelitian dengan melalukan wawancara dengan berbagai informan dilapangan terlihat bahwa proses komunikasi yang dibangun dalam pelaksanaan peraturan daerah nomor 3 Tahun 2016 mengenai pengelolaan sampah belum terlaksana dengan baik meskipun pihak kelurahan sendiri sudah berusaha semaksimal mungkin agar dapat menyampaikan di setiap kesempatan yang ada faktanya ini tidak memadai, kurangnya komunikasi yang di bangun antara kelurahan dengan lembaga yang berada dibawahnya seperti RT dan RW menyebabkan peraturan daerah tersebut tidak sampai ke sebagian besar masyarakat Kota Palu , ini di tunjukan dengan masih banyak masyarakat yang tidak mengetahui peraturan daerah yang ada, ditambah lagi ada wilayah yang dimana RT nya tidak pernah di beritahukan mengenai peraturan daerah tersebut. Sementara itu di wilayah yang sempat di beritahukan peraturan daerah padahal terjun dari sosialisasi sendiri yaitu agar masyarakatnya dapat mematuhi dan melaksanakan program yang ada.

Untuk mendukung terlaksananya aspek komunikasi diperlukan koordinasi namun realitasnya koordinasi para implementor kebijakan dalam hal ini dinas kebersihan, kecamatan, kelurahan, RT dan RW bersama masyarakat masih kurang optimal terlihat dari beberapa RT dan RW masih belum memahami adanya peraturan daerah terkait pengelolaan sampah. Menurut Van Horn dan Van Meter implemntasi kebijakan dibutuhkan dukungan koordinasi dalam hal ini instansi lain untuk keberhasilan program 
pengelolaan sampah. Koordinasi yang dijalankan dalam rangka untuk memenuhi penyedian sarana dan prasarana dalam rangka penanganan, pelayanan persoalan sampah. Tidak hanya persoalan sampah juga membutuhkan komunikasi dan koordinasi dengan pihak swasta dalam hal ini pelaku usaha untuk duduk bersama menangani persoalan sampah.

\section{Sumber Daya}

Sumber daya dapat dilihat dari sumber daya manusia. Pelaksanaan program pengelolaan sampah diperlukan aspek ketersedian pelaksana program dalam hal ini yaitu tenaga seperti tenaga administrasi dan tenaga buruh pengangkut sampah. Sumber daya manusia menjadi modal dalam mendorong terwujudnya pelayanan dan pengelolaan sampah dalam menjaga kebersihan di kota Palu. Menurut Agustino (2012) bahwa sumber daya menjadi salah faktor utama dalam mengimplementasikan kebijakan. Sumber daya manusia yang memilik keahlian membawah nilai positif akan keberhasilan sebuah kebijakan atau program. Implementsi kebijakan harus ditunjang dengan sumber daya, baik sumber daya manusia, materi maupun metode. Sasaran, tujuan, dan isi kebijakan walaupun sudah di komunikasikan secara jelas dan konsisten, apa bila implementor kekurangan sumber daya untuk pelaksanaan, implementasi tidak akan berjalan dengan efektif dan efesien. Tanpa sumberdaya kebijakan tidaka dapat di wujudkan untuk memberikan pemecahan masalah yang ada di masyarakat dan upaya memberikan pelayanan pada masyarakat. Pada dasarnya sumberdaya tersebut dapat berwujud sumberdaya manusia, yaitu kompetensi implementor dan sumberdaya finansial.

Kota Palu sendiri merupakan Ibu Kota dari Profinsi Sulawesi Tengah yang menunjukan bahwa Kota Palu sendiri dapat membiayai program-program daerahnya sendiri tentuunya tidak diragukan lagi Kota ini memiliki sumberdaya manusia dan sumber daya finansial untuk menjalankan setiap program kerja yang ada. Di dalam perda yang ada sumberdaya manusia sebagai pendukung utama yaitu diserahkan kepada organisasi perangkat daerah terkait hal ini ter tulis dalam pasal 4A peraturan daerah nomor 3 Tahun 2016 selain organisasi perangkat daerah terkait pemerintah juga membentuk kelompok satuan tugas kebersihan yang berasal dari organisasi perangkat daerah terkait, unsur kecamatan, unsur kelurahan, pemerhati lingkungan, dan lembaga pemberdayaan masyarakat sebagaimana yang tetuang dalam pasal 4 ayat $1 \mathrm{~A}$ poin ke 3 dan juga pemerintah bertanggung jawab atas pengadaan saran pengangkutan sampah seperti yang tertera di dalam pasal 13 A dan pasal $13 \mathrm{~B}$

Hasil wawancara dengan beberapa informan peneliti menyimpulkan bahwa pembagian sumber daya di bagian tidak merata, sehingga sebagian masyarakat kelurahan mengeluh dengan kondisi yang ada, sebenarnya jika sarana tempat pembuangan sampah tersedia seperti TPS maka ini akan mengurangi masyarakat yang membuang sampah sembarangan. Karena kurangnya TPS yang di sediakan sehingga sebagian besar masyarakat membuang sampahnya sembarangan yang akibatnya mengotori lingkungan, dari pihak RT sendiri menjadi bingung karena jiika di berlakukan perda yang ada terus masyarakat mau membuang sampah kemana?, dari pihak pemerintah kota sendiri belum ada pengadaan tempat pembuangan sampah, padahal pemerintah bertanggung jawab atas pengadaan saran pengangkutan sampah seperti yang tertera di dalam pasal 13 A dan pasal $13 \mathrm{~B}$.

Begitupula dengan sumberdaya manusianya yang belum merata di sebagian wilayah, ada yang belum di bentuk Kelompok Swadaya Masyarakat untuk mengelolah sampah, sementara di beberapa kelurahan sudah di bentuk tetapi belum diadakan pembinaan pengelolaan sampah, padahal pemerintah kota sendiri di dalam peraturan daerah yang ada di haruskan melakukan pembinaan. 
Menurut George C. Edward III bahwa sarana dan prasarana menjadi penting sehingga keterbasan tersebut bisa mengakibatkan impelementasi kebijakan tidak berjalan dengan baik. Keterbatasan sarana dan prasarana akan memberikan dampak negatif terhadap terselenggaranya program pengelolaan sampah di Kota Palu. Sehingga sarana dan prasarana seperti tempat pembuangan sampai serta dalam hal mobil armada pengangkut sampah perlu kembali ditinjau kembali sehingga akses masyarakat membuang sampah terlayani.

Pemerintah kota Palu juga perlu mengambil contoh terhadap pengelolaan sampah di perumahan dosen Untad yang dikelola pengurus mesjid menyediakan armada sampah mengangkut sampah rumah tangga masyarakat perumahan dosen ke tempat akhir pembuangan sampah. Masyarakat di perumahan dosen membayar iuran sebesar $\mathrm{Rp} 50.000$ ke pengelola mesjid sebagai biaya operasional mengangkut sampah selebihnya sebagai kas mesjid tersebut. Artinya masalah sampah perlu melibatkan sumber daya dalam hal ini masyarakat untuk mengatasi permasalahan sampah yang selama ini dipandang negatif padahal sampah bisa menghasilkan nilai ekonomis.

\section{Disposisi}

Disposisi adalah sikap pelaksana menjadi faktor penting dalam menjalankan program kebijakan pengelolaan sampah. Sikap pelaksana menjadi ujung tombak keberhasilan kebijakan sehingga dibutuhkan kesamaan pandangan atau tujuan sikap pelaksana. Jika pandangan pelaksana kebijakan berbeda tentunya akan jauh dari tujuan yang diharapkan. Intensitas disposisi sangat diperlukan dalam pelaksanaan kebijakan. Menurut Edward III keberhasilan implementasi sebuah kebijakan yang efektif dan efesien terletak pada implementor tidak hanya bagaimana upaya yang dilakukan untuk menyukseskan kebijakan tersebut tetapi dilihat dari sejauh mana kemauan implementor melaksanakan sebuah kebijakan atau program.
Disposisi merupakan karakteristik yang dimiliki oleh pelaksana kebijakan diantaranya komitmen untuk menjalankan tugas serta kejujuran dalam bekerja. Pada dasarnya jika disposisi para pelaksana kebijakan bekerja dengan baik maka sesungguhnya implemntasi kebijakan akan berjalan dengan efektif. Dalam peraturan daerah ini yang menjadi implementator adalah organisasi perangkat daerah terkait, unsur kecamatan, unsur kelurahan, pemerhati lingkungan, dan lembaga pemberdayaan masyarakat yang diatur dalam peraturan daerah nomor 3 Tahun 2016 pasal 4 ayat $1 \mathrm{~A}$ ayat ke 3 . Di satu sisi pemerintah daerah di haruskan berperan aktif dalam mengawasi jalannya para implementator dengan melakukan kegiatan pembinaan pengolaan sampah dan pengawasan sebagaiman yang di maksud dalam pasal $40 \mathrm{~A}$ ayat 1 dan $40 \mathrm{~B}$ ayat 1 .

Hasil wawancara yang dilakukan maka peneliti berkesimpulan bahwa disposisi dalam penyelenggaraan peraturan daerah ini kurang baik. Disposisi adalah watak dan karakteristik yang dimiliki oleh implementor, seperti komitmen, kejujuran, sifat demokratis. Poin-poin ini dapat dilihat dari sejauh mana keterlibatan atau peran pemerintah dalam menerapkan peraturan daerah ini di masyarakat meskipun beberapa pihak mengatakan bahwa peran pemerintah kota dan kelurahan sudah sangat besar dalam penanganan sampah tetapi peran ini belum berdampak apa-apa bagi masyarakat sehingga masyarakat mengatakan bahwa peran pemerintah kota maupun kelurahan belum ada, patut di akui bahwa peran pemerintah kota ataupun kelurahan belum dapat dirasakan oleh masyarakat sehingga komitmen dalam menjalankan peraturan daerah yang ada itu masih kurang, jika implementor memiliki disposisi yang baik ia akan menjalankan menjalankan kebijakan dengan baik, seperti apa yang di inginkan oleh pembuat kebijakan, maka proses implementasi menjadi efektif.

Penanganan sampah di Kota Palu perlu menjadi perhatian komiten dan 
kemauan membuat kota Palu menjadi bersih diperlukan kerjasama semua stake holder bukan hanya tanggung jawab pemerintah semata namun masyarakat bersama pelaku usaha harus turut menyukseskan kebijakan tersebut sehingga kota Palu sebagai ibu Kota Provinsi menjadi percontohan bagi kebersihan kabupaten-kabupaten yang lain.

\section{Struktur Birokrasi}

Struktur organisasi memiliki peranan dalam proses implementasi kebijakan (Solihin, 2015). Struktur organisasi menjalankan tugasnya berdasarkan standar atau pedoman yang telah ditetapkan dalam sebuah organisasi. Struktur organisasi yang selama ini dikenal terkadang cenderung melemahkan pengawasan yang berujung birokrasi terkesan rumit sehingga aktifitas oranisasi tidak berjalan dengan baik. Dalam peraturan daerah ini struktur birokrasi di muat dalam pasal $4 \mathrm{~A}$ ayat 1 dan 2 yang mana memuat struktur birokrasi dari yang paling atas sampai bawah yang bertanggung jawab dalam pengolahan sampah

Hasil wawancara dengan beberapa informan maka peneliti berkesimpulan bahwa penerapan struktur birokrasi dalam peraturan daerah ini kurang baik karena ketidak jelasan pembentukan kepengurusan pengelolah sampah dan juga sistem kerjanya yang tidak memiliki SOP yang baik, memang berdasarkan keterangan yang diberikan oleh salah satu pegawai dari kelurahan bahwa sudah ada pembentukan pengurus pengolah sampah yaitu satgas K5 yang di ketuai oleh Pak Lurah sendiri namun dalam keterangan warga yang lain kegiatan yang di lakukan satgas ini tidak berdampak besar bagi warga dalm masalah sampah, dan di sebagian wilayah RT tidak ada pembentukan pengelolah sampah dari pemerintah kota maupun kelurahan, yang seharusnya pemerintah melalui kelurahan membentuk kepengurusan pengelola sampah di setiap Kompleks pemukiman warga berkordinasi dengan RT dan RW setempat sebagaimana yang tercantum dalam pasal 4 A ayat 1 dan 2 .

Struktur birokrasi salah satu faktor dalam implementasi kebijakan namun pengelolaan sampah di Kota Palu jika dilihat dari aspek struktur birokrasi masih kurang optimal sebab pembentukan satgas K5 tidak berjalan optimal sebab tidak ada bagian tersendiri dalam stuktur satgas K5 mangatur mengenai pengelolaan sampah. Sehingga dibutuhkan kejelasan dalam regulasi tugas dan fungsi para pelaksana kebijakan. Pengurangan sampah masih belum memperlihatkan hasil sebab pengelolaan sampah masih belum memiliki kejelasan menjadi tanggungjawab sepenuhnya pada siapa. Meskipun ada organisasi perangkat daerah dalam hal ini dinas kebersihan namun kinerja masih dipertanyakan sebab sampah masih berserakkan dimana-mana bahkan bertumpuk beberapa hari tidak diangkut dengan alasan tidak uang tranportasi armada.

\section{Kesimpulan}

Berdasarkan hasil penelitian dari datadata yang di dapat dan di uraikan dalam bab sebelumnya, maka dapat di tarik sebuah kesimpulan dari implementasi kebijakan peraturan daerah Kota Palu mengenai pengolahan sampah masih kurang baik dari berbagai aspek dan belum sesuai dengan isi dan tujuan yang diharapkan dari peraturan yang ada, hal ini dikarenakan masih banyaknya kendala yang di hadapi, dilihat dari segi komunikasi, sumberdaya, disposisi, dan struktur birokrasi, yaitu komunikasi yang belum berjalan dengan baik karena penyampaian informasi belum merata, tidak efektif serta tidak maksimalnya upaya yang dilakukan pemerintah Kelurahan dala penyampaian informasi kepada masyarakat selaku implementor. Sumberdaya untuk mendukung implementasi kebijakan juga masih sangat kurang terutama dari segi penyediaan TPS (tempat pembuangan sementara) sebagai salah satu sumberdaya fasilitas, serta kurangnya semberdaya 
finansial untuk mendanai pengadaan sarana dan prasarana. Disposisi atau sikap dari implementor yang kurang tegas dalam mengaplikasikan kebijakan yang ada, serta kurangnya komitmen bersama yang di bangun dengan warga untuk menjaga lingkungan. Struktur birokrasi yaitu tidak adanya penerapan prosedur sebagaimana yang tercantum dalam peraturan daerah tersebut sebagai pedoman dalam mengelolah sampah sehingga implementasi kebijakan menjadi tidak terlaksana dengan baik.

\section{Referensi}

Aditya, A. F. (2020). KLHK: Jumlah Sampah Nasional 2020 Mencapai 67,8 Juta Ton. IDN Times. https://www.idntimes.com/news/indon esia/aldzah-fatimah-aditya/klhkjumlah-sampah-nasional-2020mencapai-678-juta-ton

Agustino, L. (2008). Dasar-Dasar Kebijakan Publik. Alfabeta.

Akib, H. (2010). IMPLEMENTASI

KEBIJAKAN: Apa, Mengapa, dan Bagaimana HAEDAR AKIB. In Haedar Akib/ (Vol. 1, Issue 1).

Budiman, R. (2013). Budiman Rusli. Hakim Publishing.

Cangara, H. H. (2016). Komunikasi Politik: Konsep, Teori dan Strategi. PT. Raja Grafindo Persada.

Djunaidi, M. (2018). Pelatihan Pengolahan Limbah Kertas (Vol. 1, Issue 2).

Dunn, W. N. (2003). Analisis Kebijakan Publik. Gadjah Mada University Press.

Fadli, M., Muhlis, \& Lutfi, M. (2016). Hukum dan Kebijakan Lingkungan. UB Press.

Hernawati, D., \& Saleh, C. (2015).

PARTISIPASI MASYARAKAT

DALAM PENGELOLAAN

SAMPAH BERBASIS 3R (REDUCE, REUSE DAN RECYCLE) (STUDI

PADA TEMPAT PENGELOLAAN

SAMPAH TERPADU DI DESA MULYOAGUNG KECAMATAN DAU KABUPATEN MALANG). In $J A P)$ (Vol. 1, Issue 2). www.kompasiana.com

Littlejohn, Stephen. W. \& Foss, K. A. (2011). Teori Komunikasi. Salemba Humanika.

Mahyudin, R. P. (2017). STUDY OF WASTE PROBLEMS AND LANDFILL ENVIROMENTAL IMPACT. In Jukung Jurnal Teknik Lingkungan (Vol. 3, Issue 1).

Miles, M. B. and A. M. H. (2005). Qualitative Data Analysis (terjemahan). UI PRess.

Moleong, L. J. (2012). Metode Penelitian Kualitatif. Remaja Rosdakarya.

Nugroho, R. (2017). Public Policy (6th ed.). PT Elex Media Kompotindo Kompas Gramedia.

Parwata, I. G. N., Hukum, F., \& Udayana, U. (2011). SUWUNG KAUH SEBAGAI TEMPAT PEMROSESAN AKHIR ( TPA ) SUWUNG I Putu Oka Suyasa * Desa Suwung Kauh, Kecamatan Denpasar Selatan, Kota Denpasar. c, 1-15.

Solihin, A. W. (2015). Analisis Kebijakan Dari Formulasi Ke Penyusunan Model-model Implementasi Kebijakan Publik. PT Bumi Aksara.

Sujiyanto, S. (2016). Analisis Pengelolaan Sampah Di Bank Sampah Malang. Jurnal Ilmu Sosial Dan Ilmu Politik Universitas Tribhuwana Tunggadewi, 5(3), 102218.

Suryana. (2018). GEOAREA, Vol 1.No. 1_Mei 2018.1(1). 
KINESIK Vol. 8 No. 1 (2021) | 61 